\title{
ANALISIS TEORI KEADILAN DALAM KONTRAK KERJA KONSTRUKSI DAN ASPEK PENYELESAIAN SENGKETANYA
}

\author{
Mariske Myeke Tampi \\ Staf Pengajar Fakultas Hukum, Universitas Tarumanegara \\ Korespondensi: mariske.tampi@gmail.com
}

\begin{abstract}
Abstrak
Kontrak jasa konstruksi disusun oleh penyedia jasa konstruksi dan pengguna jasa konstruksi (sektor swasta atau pemerintah). Seringkali persiapan kontrak kerja konstruksi dilakukan secara tidak seimbang karena kontrak disiapkan oleh salah satu pihak, yaitu penyedia jasa konstruksi. Oleh karena itu, kontrak kerja konstruksi yang dikaitkan dengan teori keadilan oleh John Rawls menjadi issue yang menarik. Dalam artikel ini, penulis akan menelaah keseimbangan yang seharusnya ada dalam kontrak kerja kontruksi yang seharusnya diwujudkan oleh kedua pihak dalam menyusun kontrak kerja kontruksi.Selanjutnya juga akan dianalisis mengenai penyelesaian sengketa dari sudut pandang hukum perdata. Penyelesaian berdasar hukum perdata merupakan sesuatu yang masuk akal mengingat pada dasarnya, issue yang diselesaikan adalah wanprestasi.
\end{abstract}

Kata-kata Kunci: Kontrak Kerja Kontruksi; Teori Keadilan; Penyelesaian Sengketa.

\begin{abstract}
Construction service contracts are concluded by and between the service provider (providers of construction services) and the service user (private or government). Frequently, the preparation of construction contracts are unequal because the contract has already been prepared by one party (service user). Therefore, it is an interesting issue to associate unequal construction contracts with the theory of justice promoted by John Rawls. In this article, the author will examine the balance that should exist in the construction contract that should be realized by both parties in the contract. Later on, the resolution of the dispute emerging from construction contract will also be analyzed from the civil law perspective. Dispute settlement based on civil law is basically appropriate considering that at the last resort, the relevant issue is breach of contract.
\end{abstract}

Key words: Construction Contracts; Theory of Justice; Dispute Resolution. 


\section{PENDAHULUAN}

Jasa konstruksi adalah layanan jasa konsultasi perencanaan pekerjaan konstruksi, layanan jasa pelaksanaan pekerjaan konstruksi dan layanan jasa konsultasi pengawasan pekerjaan konstruksi (Pasal 1 angka 1 UndangUndang Nomor 18 Tahun 1999 tentang Jasa Konstruksi - UU No. 18 Tahun 1999). Jasa konstruksi mempunyai peranan yang penting dan strategis mengingat jasa konstruksi menghasilkan produk akhir berupa bangunan atau bentuk fisik lainnya, baik yang berupa prasarana maupun sarana yang berfungsi mendukung pertumbuhan dan perkembangan di berbagai bidang.

Hal yang menarik dalam jasa konstruksi adalah asumsi khalayak umum mengenai kontrak kerja konstruksi adalah bahwa pengguna jasanya hanya terbatas pemerintah. Padahal dalam Pasal 1 angka 3 UU No. 18 Tahun 1999, pengguna jasa adalah perseorangan atau badan sebagai pemberi tugas atau pemilik pekerjaan/ proyek yang memerlukan layanan jasa konstruksi. Dengan kata lain, pihak pengguna jasa tidak hanya terbatas pada pemerintah, sehingga diperlukan klarifikasi lebih lanjut mengenai siapa saja para pihak dalam yang terlibat dalam kontrak kerja konstruksi.

Problematika lainnya dalam kontrak kerja konstruksi adalah mengenai kesetaraan kedudukan antara para pihak, yaitu penyedia jasa dan pengguna jasa. Seyogyanya, menurut teori keadilan (John Rawls), para pihak memiliki kedudukan yang setara dalam pembentukan kontrak kerja konstruksi. Sebelum masuk ke ranah pembentukan kontrak senyatanya di lapangan, seyogyanya kesetaraan kedudukan pengguna jasa dan penyedia jasa telah terlebih dahulu diatur dalam pengaturan mengenai jasa konstruksi.

Problematika dalam pengadaan jasa konstruksi yang sedang marak akhirakhir ini adalah kontrak kerja konstruksi yang pihak pengguna jasanya adalah pemerintah (selanjutnya disebut kontrak kerja konstruksi pemerintah), kaitannya dengan tindakan hukum pemerintah dalam kontrak tersebut berada di ranah hukum mana: publik atau privat. Seperti halnya, tindakan hukum pemerintah dalam kontrak pembangunan Jalan Lingkar Selatan (JLS) tahun 2008, yang para pihaknya adalah Pemerintah Kota Salatiga, dalam hal ini diwakili oleh Pejabat Pembuat Komitmen (PPKom) dari Dinas Pekerjaan Umum Salatiga sebagai pengguna jasa dan Direktur PT. Kuntjup - PT. Kadi International sebagai penyedia jasa.

Kontrak kerja konstruksi yang seharusnya berada pada ranah hukum perdata seringkali langsung dikaitkan dengan ranah hukum administrasi dan ranah hukum pidana karena asumsi bahwa tindakan hukum pemerintah adalah perbuatan hukum publik yang sumber dananya adalah APBN/APBD. Hal ini hangat diperbincangkan dalam Seminar Nasional bertajuk "Status Hukum Kontrak Kerja Konstruksi: Kesucian Kontrak vs Kriminalisasi” yang diselenggarakan oleh Fakultas Hukum 
dan Magister Ilmu Hukum UKSW bekerja sama dengan LPJK-D Jateng dan BPD Jateng pada tahun 2010.

Seminar tersebut sama sekali tidak membahas mengenai Peraturan Pemerintah Nomor 29 Tahun 2000 tentang Penyelenggaraan Jasa Kontruksi (PP No. 29 Tahun 2000). Padahal PP No. 29 Tahun 2000 (telah diubah dengan PP No. 59 Tahun 2010) tersebut penting berkaitan dengan penyelenggaraan jasa konstruksi khususnya tentang kontrak kerja kontruksi, tanggung jawab para pihak dalam kontrak kerja konstruksi maupun wanprestasi (breach of contract) dalam penyelenggaraan jasa konstruksi.

Dalam Pasal 23 PP No. 29 Tahun 2000 dijelaskan secara rinci antara lain mengenai para pihak, tanggung jawab penyedia jasa dan pengguna jasa, maupun ganti rugi apabila terjadi wanprestasi dalam penyelenggaraan kontrak kerja konstruksi. Oleh karena itu, menurut penulis, PP No. 29 Tahun 2000 ini seharusnya menjadi landasan dalam pembentukan dan pelaksanaan kontrak kerja konstruksi karena PP No. 29 Tahun 2000 ini merupakan peraturan pelaksana dari UU No. 18 Tahun 1999.

Untuk selanjutnya artikel ini akan membahas mengenai hal-hal sebagai berikut. Pertama, analisis teori keadilan (John Rawls) dalam pengaturan jasa kontruksi yaitu UU No. 18 Tahun 1999 dan PP No. 29 Tahun 2000. Kedua, pilihan penyelesaian jika terjadi wanprestasi (breach of contract) dalam kontrak kerja jasa konstruksi. Ketiga, secara khusus, pilihan penyelesaian sengketa dalam kontrak kerja konstruksi pemerintah.

\section{PEMBAHASAN}

\section{Landasan Teoretis tentang Teori Keadilan dan Wanprestasi (Breach of Contract)}

Landasan teoretis yang digunakan di sini adalah teori keadilan dan wanprestasi. Berikut uraian mengenai kedua hal tersebut.

Teori Keadilan

Teori Keadilan yang dikemukakan oleh John Rawls bertitik tolak pada terma Posisi Asali yaitu status quo awal yang menegaskan bahwa kesepakatan fundamental yang dicapai adalah fair. ${ }^{1}$ Semua orang mempunyai hak yang sama dalam prosedur memilih prinsip; setiap orang bisa mengajukan usulan, menyampaikan penalaran mereka, dan lain-lain. ${ }^{2}$

Dalam konteks ini Rawls menyebut "justice as fairness" yang ditandai dengan adanya prinsip rasionalitas, kebebasan dan kesamaan. Oleh karena itu diperlukan prinsip-prinsip keadilan yang lebih mengutamakan asas hak daripada asas manfaat. Salah satu prinsip keadilan distributif yang dikemukakan oleh Rawls yaitu prinsip

John Rawls, A Theory of Justice: Teori Keadilan (Pustaka Pelajar 2006) 19.

Agus Yudha Hernoko, Hukum Perjanjian Asas Proporsionalitas dalam Kontrak Komersial, (Laksbang Mediatama 2008) 21. 
the greatest equal principle, bahwa setiap orang harus memiliki hak yang sama atas kebebasan dasar yang paling luas, seluas kebebasan yang sama bagi semua orang. Ini merupakan hak yang paling mendasar (hak asasi) yang harus dimiliki semua orang. Dengan kata lain, hanya dengan adanya jaminan kebebasan yang sama bagi semua orang, maka keadilan akan terwujud (Prinsip Kesamaan Hak). ${ }^{3}$

Menurut Agus Yudha Hernoko, the greatest equal principle adalah "prinsip kesamaan hak" yang merupakan prinsip yang memberikan kesetaraan hak dan tentunya berbanding terbalik dengan beban kewajiban yang dimiliki oleh setiap orang. Prinsip ini merupakan roh dari asas kebebasan berkontrak. ${ }^{4}$

Wanprestasi (breach of contract)

Wanprestasi (breach of contract) seringkali dipersamakan dengan terma cidera janji, ingkar janji, atau prestasi buruk yang artinya tidak melakukan kewajiban kontraktualnya sesuai dengan kesepakatan yang dibuatnya. Wujud wanprestasi dapat berupa : a) Tidak melakukan apa yang disanggupi untuk dilakukan; b) Melaksanakan apa yang diperjanjikan, tetapi tidak sebagaimana yang diperjanjikan; c) Melakukan apa yang diperjanjikan tetapi terlambat; d) Melakukan sesuatu yang menurut perjanjian tidak boleh dilakukan. Sedangkan akibat hukum debitur wanprestasi: a) Membayar ganti rugi; b)Pembatalan perjanjian; c)
Peralihan risiko; dan d) Pembayaran biaya perkara. ${ }^{5}$

\section{Analisis Pengaturan mengenai Kontrak Kerja Konstruksi}

Berikut ini pengaturan mengenai kontrak kerja kontruksi dalam UndangUndang Nomor 18 Tahun 1999 tentang Jasa Kontruksi (UU No. 18 Tahun 1999) dan Peraturan Pemerintah Nomor 29 Tahun 2000 tentang Penyelenggaraan Jasa Konstruksi (PP No. 29 Tahun 2000).

Definisi Kontrak Kerja Konstruksi

Kontrak Kerja Konstruksi adalah keseluruhan dokumen yang mengatur hubungan hukum antara pengguna jasa dan penyedia jasa dalam penyelenggaraan pekerjaan kontruksi (Pasal 1 angka 5 UU No. 18 Tahun 1999). Kontrak kerja konstruksi diatur dalam Pasal 22 UU No. 18 Tahun 1999 dan Pasal 20-23 PP No. 29 Tahun 2000. Kontrak kerja konstruksi pada dasarnya dibuat secara terpisah sesuai dengan tahapan dalam pekerjaan konstruksi yang terdiri dari kontrak kerja konstruksi untuk pekerjaan perencanaan, kontrak kerja konstruksi untuk pekerjaan pelaksanaan dan kontrak kerja konstruksi untuk pekerjaan pengawasan (Pasal 20 ayat (1) PP No. 29 Tahun 2000). Dalam hal pekerjaan terintegrasi, kontrak kerja konstruksi dapat dituangkan dalam 1 (satu) kontrak kerja konstruksi (Pasal 20 ayat (2) PP No. 29 Tahun 2000).

Nindyo Pramono, Status Hukum Kontrak Kerja Konstruksi: Kriminalisasi vs Kesucian Kontrak, (Seminar Nasional FH UKSW Salatiga 2010). 
Prinsip Keseimbangan dalam Kontrak Kerja Konstruksi

Pasal 2 UU No. 18 Tahun 1999 dinyatakan bahwa asas yang melandasi pengaturan jasa konstruksi adalah antara lain asas keadilan dan keseimbangan. Selain itu, dalam Pasal 3 b UU No. 18 Tahun 1999, dinyatakan bahwa salah satu tujuan pengaturan jasa konstruksi adalah "untuk menjamin kesetaraan kedudukan antara Pengguna Jasa dan Penyedia Jasa dalam hak dan kewajiban, serta meningkatkan kepatuhan kepada ketentuan perundang-undangan yang berlaku.”

Para Pihak dalam Kontrak Kerja Konstruksi

Para pihak dalam kontrak kerja konstruksi adalah pengguna jasa dan penyedia jasa. Pengguna jasa adalah perseorangan atau badan sebagai pemberi tugas atau pemilik pekerjaan/ proyek yang memerlukan layanan jasa konstruksi. Penyedia jasa adalah orangperseorangan atau badan yang kegiatan usahanya menyediakan layanan jasa kontruksi. (Pasal 1 angka 3 dan 4 UU No. 18 Tahun 1999).

Dalam Kontrak Kerja Konstruksi harus dimuat uraian mengenai para pihak yaitu: (1) akta badan usaha atau usaha perseorangan; (2) nama wakil/ kuasa badan usaha sesuai kewenangan pada akta badan usaha atau sertifikat keterampilan kerja bagi usaha perorangan; dan (3) tempat kedudukan dan alamat badan usaha atau usaha orang perseorangan. (Pasal 23 ayat (1) huruf a PP No. 29 Tahun 2000). Penyedia jasa kontruksi yang merupakan perseorangan hanya dapat melaksanakan pekerjaan konstruksi yang berisiko kecil yang berteknologi sederhana dan yang berbiaya kecil. Sedangkan pekerjaan konstruksi yang berisiko besar dan/atau yang berteknologi tinggi dan/atau yang berbiaya besar hanya dapat dilakukan oleh badan usaha yang berbentuk perseroan terbatas dan badan usaha yang dipersamakan.

Ruang Lingkup Kontrak Kerja Konstruksi

Ruang lingkup kontrak kerja konstruksi mencakup definisi pekerjaan konstruksi yaitu keseluruhan atau sebagian rangkaian kegiatan perencanaan dan/atau pelaksanaan beserta pengawasan yang mencakup pekerjaan arsitektural, sipil, mekanikal, elektrikal dan tata lingkungan masingmasing beserta kelengkapannya, untuk mewujudkan suatu bangunan atau bentuk fisik lain (Pasal 1 angka 2 UU No. 18 Tahun 1999).

Kontrak kerja konstruksi sekurangkurangnya harus mencakup uraian mengenai:

a. Para pihak, yang memuat secara jelas identitas para pihak;

b. Rumusan pekerjaan, yang memuat uraian yang jelas dan rinci tentang lingkup kerja, nilai pekerjaan dan batasan waktu pelaksanaan;

c. Masa pertanggungan dan/atau pemeliharaan, yang memuat tentang jumlah, klasifikasi dan kualifikasi 
tenaga ahli untuk melaksanakan pekerjaan konstruksi;

d. Tenaga ahli, yang memuat ketentuan tentang jumlah, klasifikasi dan kualifikasi tenaga ahli untuk melakukan pekerjaan konstruksi;

e. Hak dan kewajiban, yang memuat hak pengguna jasa untuk memperoleh hasil pekerjaan konstruksi serta kewajibannya untuk memenuhi ketentuan yang diperjanjikan serta hak penyedia jasa serta kewajibannya melaksanakan pekerjaan konstruksi;

f. Cara pembayaran, yang memuat ketentuan tentang kewajiban pengguna jasa dalam melakukan pembayaran hasil pekerjaan konstruksi;

g. Cidera janji, yang memuat ketentuan tentang tanggung jawab dalam hal salah satu pihak tidak melaksanakan kewajiban sebagaimana yang diperjanjikan;

h. Penyelesaian perselisihan, yang memuat ketentuan tentang tata cara penyelesaian perselisihan akibat ketidaksepakatan;

i. Pemutusan kontrak kerja konstruksi, yang memuat ketentuan tentang pemutusan kontrak kerja konstruksi yang timbul akibat tidak dapat dipenuhinya kewajiban salah satu pihak;

j. Keadaan memaksa (force majeure), yang memuat ketentuan tentang kejadian yang timbul di luar kemauan dan kemampuan para pihak yang menimbulkan kerugian bagi salah satu pihak;

k. Kegagalan bangunan, yang memuat ketentuan tentang kewajiban penyedia jasa dan/atau pengguna jasa atas kegagalan bangunan;

1. Perlindungan pekerja yang memuat ketentuan tentang kewajiban para pihak dalam pelaksanaan keselamatan dan kesehatan kerja serta jaminan sosial;

m. Aspek lingkungan, yang memuat kewajiban para pihak dalam pemenuhan ketentuan tentang lingkungan (Pasal 22 ayat 2 PP No. 20 Tahun 2009).

Rumusan pekerjaan dalam kontrak kerja konstruksi meliputi:

a. Pokok-pokok pekerjaan yang diperjanjikan;

b. Volume atau besaran pekerjaan yang harus dilaksanakan;

c. Nilai pekerjaan dan ketentuan mengenai penyesuaian nilai pekerjaan akibat fluktuasi harga untuk kontrak kerja konstuksi bertahun jamak;

d. Tata cara penilaian hasil pekerjaan dan pembayaran; dan

e. Jangka waktu pelaksanaan (Pasal 23 ayat (1) huruf b PP No. 29 Tahun 2000).

Pengikatan Kerja Jasa Konstruksi

Pengikatan dalam hubungan kerja konstruksi dilakukan berdasarkan prinsip persaingan sehat melalui pemilihan penyedia jasa dengan cara pelelangan umum secara terbatas. Pengikatan merupakan suatu proses yang ditempuh oleh pengguna jasa dan penyedia jasa pada kedudukan yang sejajar dalam mencapai suatu kesepakatan untuk melaksanakan 
pekerjaan konstruksi. Dalam setiap tahapan proses ditetapkan hak dan kewajiban masing-masing pihak yang adil dan serasi yang disertai dengan sanksi. ${ }^{6}$

Prinsip persaingan sehat mengandung pengertian antara lain:

a. Diakuinya kedudukan yang sejajar antara pengguna jasa dan penyedia jasa;

b. Dipenuhinya ketentuan keterbukaan dalam proses pemilihan dan penetapan;

c. Adanya peluang keikutsertaan dalam tahapan persaingan sehat bagi penyedia jasa sesuai dengan kemampuan dan ketentuan yang disyaratkan. $^{7}$

Keseluruhan pengertian tentang prinsip persaingan sehat tersebut dalam huruf (a), (b), dan (c) dituangkan dalam dokumen yang jelas, lengkap dan diketahui dengan baik oleh semua pihak serta bersifat mengikat.

Pertanggungjawaban Penyedia Jasa maupun Pengguna Jasa dalam Kontrak Kerja Konstruksi

Jenis pertanggungjawaban yang menjadi kewajiban penyedia jasa berkaitan dengan pembayaran uang muka, pelaksanaan pekerjaan, hasil pekerjaan, tenaga kerja, tuntutan pihak ketiga, tuntutan pihak ketiga dan kegagalan bangunan. Pertanggungjawaban sebagaimana tersebut di atas memuat: (1) nilai jaminan; (2) jangka waktu pertanggungan; (3) prosedur pencairan; (4) hak dan kewajiban masing-masing pihak. Dalam hal penyedia jasa tidak memenuhi kewajiban sesuai dengan kontrak kerja konstuksi, pengguna jasa dapat mencairkan selanjutnya menggunakan jaminan dari penyedia jasa sebagai kompensasi pemenuhan kewajiban penyedia jasa (Pasal 23 ayat (1) huruf c PP No. 29 Tahun 2000).

Penyedia jasa maupun pengguna jasa harus bertanggung jawab apabila terjadi:

a. Kegagalan Pekerjaan Konstruksi (seperti disebutkan dalam Pasal 1 angka 2 UU No. 18 Tahun 1999) yaitu keadaan hasil pekerjaan konstruksi baik sebagian maupun keseluruhan tidak sesuai dengan spesifikasi pekerjaan sebagaimana disepakati dalam kontrak kerja kontruksi baik sebagian maupun keseluruhan sebagai akibat kesalahan Pengguna Jasa atau Penyedia Jasa (Pasal 31 PP No. 29 Tahun 2000);

b. Kegagalan Bangunan yaitu keadaan bangunan tidak berfungsi, baik secara keseluruhan maupun sebagian dari segi teknis, manfaat dan kesehatan kerja, dan atau keselamatan umum sebagai akibat kesalahan Penyedia Jasa dan/atau Pengguna Jasa setelah penyerahan

Abdulkadir Muhammad, Hukum Perusahaan Indonesia (PT. Citra Aditya Bhakti 2010) 598. Ibid. 
akhir pekerjaan konstruksi (Pasal 34 PP No. 29 Tahun 2000).

Wanprestasi dalam Kontrak Kerja Konstruksi

Wanprestasi dalam kontrak kerja konstruksi adalah hal di mana para pihak dalam kontrak kerja konstruksi tidak memenuhi apa yang menjadi kewajibannya. Perbuatan penyedia jasa dapat dikategorikan wanprestasi apabila: (1) Tidak menyelesaikan tugas; (2) tidak memenuhi mutu; (3) tidak memenuhi kualitas; dan/atau (4) tidak menyerahkan hasil pekerjaan. Sementara perbuatan pengguna jasa yang dapat dikategorikan wanprestasi adalah: (1) terlambat membayar; (2) tidak membayar; (3) terlambat menyerahkan sarana pelaksanaan pekerjaan (Pasal 23 huruf g 1) PP No. 20 Tahun 2009). Penyedia jasa maupun pengguna jasa harus bertanggung jawab apabila terjadi wanprestasi berupa: kegagalan pekerjaan konstruksi (Pasal 31 PP No. 29 Tahun 2000); atau kegagalan bangunan (Pasal 34 PP No. 29 Tahun 2000).

Ganti rugi atas Wanprestasi

Dalam hal terjadi wanprestasi (breach of contract) yang dilakukan oleh penyedia jasa atau pengguna jasa yaitu tidak melakukan tanggung jawab yang tercantum dalam Pasal 23 ayat (1) huruf c PP No. 29 Tahun 2000) maka pihak yang dirugikan berhak untuk memperoleh kompensasi, penggantian biaya dan atau perpanjangan waktu, perbaikan atau pelaksanaan ulang hasil pekerjaan yang tidak sesuai dengan yang diperjanjikan atau pemberian ganti rugi (Pasal 23 huruf g 2 PP No. 20 Tahun 2009).

\section{Analisis Teori Keadilan (John Rawls) terhadap UU No. 18 Tahun 1999 dan PP No. 29 Tahun 2000}

Berikut ini analisis teori keadilan (John Rawls) dalam UU No. 18 Tahun 1999 dan PP No. 29 Tahun 2000.

Analisis Teori Keadilan dalam UU No. 18 Tahun 1999

Teori keadilan yang dikemukakan oleh Rawls berintikan pada "justice as fairness" yang ditandai dengan adanya prinsip rasionalitas, kebebasan dan kesamaan hak bagi setiap orang. Kesetaraan yang dimaksud terejawantahkan dalam Pasal 2 UU No. 18 Tahun 1999 di mana dinyatakan bahwa asas yang melandasi pengaturan jasa konstruksi adalah antara lain asas keadilan dan keseimbangan. Selain itu, dalam Pasal 3 b UU No. 18 Tahun 1999 dinyatakan bahwa salah satu tujuan pengaturan jasa konstruksi adalah "untuk menjamin kesetaraan kedudukan antara Pengguna Jasa dan Penyedia Jasa dalam hak dan kewajiban, serta meningkatkan kepatuhan kepada ketentuan perundang-undangan yang berlaku."

Dari pengaturan tersebut, jelas terlihat bahwa semangat justice as fairness, terejawantahkan dalam Pasal 2 dan 3 huruf b UU No. 18 Tahun 1999 mengenai kesetaraan kedudukan antara pihak Penyedia Jasa maupun Pengguna Jasa. Kesetaraan ini seharusnya 
terwujud dalam pembentukan Kontrak Kerja Konstruksi, dimana pihak Penyedia Jasa maupun pihak Pengguna Jasa memiliki hak untuk mengadakan negosiasi pada saat pembentukan kontrak tersebut.

Namun demikian, dalam praktik, kontrak kerja konstruksi terutama kontrak kerja konstruksi pemerintah, telah dirumuskan terlebih dahulu oleh pengguna jasa (pemerintah) dalam bentuk kontrak baku (standard contract). Kontrak baku tersebut menghilangkan hak dari pihak penyedia jasa untuk mengadakan negosiasi pada saat pembentukan kontrak, sehingga posisi para pihak tidak setara. Pihak penyedia jasa hanya dapat memilih antara dua: menerima atau menolak kontrak kerja konstruksi yang telah dirumuskan oleh pengguna jasa terlebih dahulu.

Dalam konteks ini, teori keadilan yang berintikan justice as fairness terejawantahkan dalam Pasal 2 dan 3 UU No. 18 Tahun 1999, mengenai kesetaraan kedudukan antara pihak penyedia jasa dan pengguna jasa. Namun dalam kenyataannya, terjadi kesenjangan antara pengaturan mengenai pembentukan kontrak kerja konstruksi (das sollen) dan praktik pembentukan kontrak kerja konstruksi (das sein) karena kontrak kerja konstruksi sudah dibentuk terlebih dahulu oleh pengguna jasa, sehingga tidak mengakomodasi kesetaraan kedudukan tersebut.

Analisis Teori Keadilan terhadap PP No. 29 Tahun 2000 atas Isu Tanggung Jawab Penyedia Jasa dan Pengguna Jasa
Tanggung jawab terdiri atas pemenuhan hak dan kewajiban yang saling berhimpit antara penyedia jasa dan pengguna jasa. Hak penyedia jasa adalah kewajiban dari pengguna jasa, demikian pula sebaliknya, hak pengguna jasa adalah kewajiban dari penyedia jasa.

Pengaturan yang seimbang antara hak dan kewajiban dari pengguna jasa maupun penyedia jasa dicantumkan dalam kontrak kerja konstruksi. Pengaturan mengenai hak dan kewajiban diatur dalam Pasal 22 ayat (2) PP No. 20 Tahun 2009 huruf a-1, yang telah dijabarkan dalam pembahasan di atas. Hak dan kewajiban Pengguna Jasa dan Penyedia Jasa, tercantum dalam Pasal 22 ayat (2) PP No. 20 Tahun 2009 huruf e dan f yaitu: hak dan kewajiban yang memuat hak pengguna jasa untuk memperoleh hasil pekerjaan konstruksi serta kewajibannya untuk memenuhi ketentuan yang diperjanjikan serta hak penyedia jasa serta kewajibannya melaksanakan pekerjaan konstruksi; dan cara pembayaran, yang memuat ketentuan tentang kewajiban pengguna jasa dalam melakukan pembayaran hasil pekerjaan konstruksi." Dari ketentuan tersebut terlihat bahwa pengaturan mengenai hak dan kewajiban pengguna jasa dan penyedia jasa diatur secara seimbang. Dengan demikian, kesetaraan kedudukan jelas terlihat sehingga prinsip keadilan terejawantahkan dalam pengaturan tersebut.

Penyelesaian Sengketa Jika Terjadi Wanprestasi 
Menurut Pasal 22 ayat (2) PP No. 20 Tahun 2009 huruf g, wanprestasi atau cidera janji (breach of contract) adalah keadaan dimana salah satu pihak tidak melaksanakan kewajiban sebagaimana yang diperjanjikan. Keadaan tersebut diuraikan dengan sangat jelas pada Pasal 23 huruf g PP No. 20 Tahun 2009.

Wanprestasi terkait dengan kegagalan pekerjaan konstruksi dan kegagalan bangunan seperti tersebut di bawah ini:

a. Kegagalan Pekerjaan Konstruksi (seperti disebutkan dalam Pasal 1 angka 2 UU No. 18 Tahun 1999) yaitu keadaan hasil pekerjaan konstruksi baik sebagian maupun keseluruhan tidak sesuai dengan spesifikasi pekerjaan sebagaimana disepakati dalam kontrak kerja kontruksi baik sebagian maupun keseluruhan sebagai akibat kesalahan Pengguna Jasa atau Penyedia Jasa (Pasal 31 PP No. 29 Tahun 2000);

b. Kegagalan Bangunan yaitu keadaan bangunan tidak berfungsi, baik secara keseluruhan maupun sebagian dari segi teknis, manfaat dan kesehatan kerja, dan atau keselamatan umum sebagai akibat kesalahan Penyedia Jasa dan/atau Pengguna Jasa setelah penyerahan akhir pekerjaan konstruksi Pasal 34 PP No. 29 Tahun 2000).

Penyelesaian sengketa diatur dalam Pasal 37 dan 38 UU No. 18 Tahun 1999. Pasal 37 mengatur tentang penyelesaian sengketa di luar pengadilan, sedangkan Pasal 38 mengatur tentang penyelesaian sengketa melalui gugatan masyarakat. Menurut hemat penulis, yang dimaksud dengan gugatan oleh masyarakat tersebut adalah gugatan perdata.

Kegagalan pekerjaan konstruksi maupun kegagalan bangunan merupakan suatu bentuk wanprestasi karena tidak sesuai dengan spesifikasi pekerjaan sebagaimana yang dimaksud dalam kontrak. Yang ditekankan dalam penyelesaian sengketa ini adalah isi kontrak bukan para pihak. Apabila bangunan tidak sesuai dengan spesifikasi yang disepakati dalam kontrak kerja konstruksi, maka penyedia jasa wanprestasi. Apabila pembayaran tidak sesuai dengan jumlah yang disepakati di dalam kontrak kerja konstruksi, maka pengguna jasa (baik swasta ataupun pemerintah) tersebut wanprestasi.

Penyelesaian Sengketa Kontrak Kerja Konstruksi Pemerintah

Dalam penyelesaian sengketa kontrak kerja konstruksi pemerintah seringkali dipermasalahkan apakah tindakan hukum pemerintah di sini masuk ke ranah hukum publik atau privat. Pemerintah yang dalam hal ini diwakili oleh Pejabat Pembuat Komitmen (PPKom), ${ }^{8}$ sebagai pengguna jasa melakukan tindakan hukum kontrak kerja konstruksi. Secara teoretis, tindakan keperdataan pemerintah tetap merupakan tindakan hukum publik yang sepihak oleh pemerintah di dalam

8 PPKom adalah pejabat yang bertanggung jawab atas pengadaan barang dan jasa. 
hukum perdata. Teori melebur menyatakan bahwa tindakan hukum publik pemerintah di dalam ranah atau bidang privat merupakan tindakan hukum perdata pemerintah.

Tindakan pemerintah merupakan perbuatan publik (hukum administrasi) namun perjanjian adalah suatu perbuatan hukum perdata (privat). Dalam hal demikian tindakan pemerintah (atau dalam hal ini keputusan) yang adalah tindakan publik dianggap melebur ke dalam perbuatan perdata. ${ }^{9}$ Berdasarkan teori melebur tersebut, maka tindakan hukum pemerintah dalam kontrak kerja konstruksi termasuk dalam ranah hukum privat.

Hal selanjutnya yang sering diperdebatkan adalah mengenai sumber dana kontrak kerja konstruksi pemerintah. Sumber dana untuk kontrak konstruksi pemerintah adalah APBN atau APBD yang merupakan belanja operasional K/l/D/I. Ketika dana APBD atau APBD itu dibelanjakan, maka yang berlaku adalah hukum perdata. Tanggung jawab pembelanjaan itu adalah pejabat yang ditunjuk untuk melaksanakan itu.

Berkaitan dengan organisasi pengadaan, Kepres 80/2003 belum mengorganisasikan secara jelas. Hal ini kemudian diperjelas dalam Perpres 54/ 2010, yaitu:
a. PA/KPA
b. PPK
c. ULP/Pejabat Pengadaan
d. Panitia/Pejabat Penerima Hasil Pekerjaan. ${ }^{10}$

Dari klasifikasi ini maka keseluruhan dari organisasi ini yang membelanjakan barang. Termasuk membuat perencanaan, pelaksanaan dan pengawasan merupakan satu kesatuan. Status uang negara berakhir ketika melakukan belanja. Jika penyedia jasa tidak melakukan pekerjaan sesuai dengan kontrak atau wanprestasi, maka penyelesaian berdasarkan kontrak; atau dengan kata lain, penyelesaian secara perdata.

\section{PENUTUP}

Kesimpulan dari artikel ini adalah sebagai berikut. Pertama, teori keadilan yang berintikan "justice as fairness" terejawantahkan dalam Pasal 2 dan 3 UU No. 18 Tahun 1999, mengenai kesetaraan kedudukan antara pihak penyedia jasa dan pengguna jasa. Dalam kenyataannya, terjadi kesenjangan antara pengaturan mengenai pembentukan kontrak kerja konstruksi dan praktik pembentukan kontrak kerja konstruksi karena kontrak kerja konstruksi sudah dibentuk terlebih dahulu oleh pengguna jasa dalam bentuk kontrak standar sehingga tidak mengakomodasi kesetaraan kedudukan tersebut.

$9 \quad$ Krishna Djaya Darumurti, 'Materi Kuliah Hukum Jasa Konstruksi' (Program Studi Magister Ilmu Hukum FH UKSW 2011).

10 Anonim, 'Matriks Perbedaan Antara Peraturan Presiden No. 54 Tahun 2010 dengan Keputusan Presiden No. 80 Tahun 2003' <http://www.khalidmustafa.info> diakses 6 Oktober 2014. 
Kedua, pengaturan mengenai hak dan kewajiban pengguna jasa dan penyedia jasa dalam PP No. 29 Tahun 2000 telah diatur secara seimbang. Kesetaraan kedudukan jelas terlihat sehingga prinsip keadilan terejawantahkan dalam pengaturan tersebut. Ketiga, penyelesaian sengketa melalui jalur perdata apabila terjadi wanprestasi diatur dalam PP No. 20 Tahun 2009. Penyelesaian sengketa melalui jalur perdata apabila terjadi wanprestasi diatur Pasal 38 UU No. 18 Tahun 1999 yaitu melalui gugatan perdata.

Keempat, penyelesaian sengketa kontrak kerja konstruksi pemerintah, berdasarkan teori melebur, merupakan tindakan hukum perdata pemerintah. Status uang negara berakhir ketika dilakukan pembelanjaan. Jika penyedia jasa tidak melakukan pekerjaan sesuai dengan kontrak atau wanprestasi, maka penyelesaian berdasarkan kontrak atau secara keperdataan.

\section{DAFTAR BACAAN}

Hernoko, Agus Yudha, Hukum Perjanjian Asas Proporsionalitas dalam Kontrak Komersial, (Laksbang Mediatama Yogyakarta 2008).

Muhammad, Abdulkadir, Hukum Perusahaan Indonesia (Citra Aditya Bhakti Bandung 2010).

Pramono, Nindyo, Status Hukum Kontrak Kerja Konstruksi: Kriminalisasi vs Kesucian Kontrak, (Seminar Nasional FH UKSW Salatiga 2010).
Rawls, John, A Theory of Justice: Teori Keadilan (Pustaka Pelajar Yogyakarta 2006).

Darumurti, Krisna Djaya. Materi Kuliah Hukum Jasa Konstruksi MIH UKSW. 2011. 